Економічні науки: збірник наукових праць Луцького національного технічного університету. Серія "Регіональна економіка". Випуск 18 (71). Редкол.: відп. ред. д.е.н., професор Л.Л. Ковальська. Луцьк: ІВВ Луцького НТУ, 2021. 278 с.

8. Ivasiv O.V. Upravlinnia proiektamy u zakladi osvity. DVNZ «Universytet menedzhmentu osvity» NAPN Ukrainy. 2020. URL: http://dspace.tnpu.edu.ua/bitstream/123456789/17176/1/4_Ivasiv.pdf.

9. Turner J., Simister S. Grower handbook of project management. $4^{\text {th }}$ Editional. $2004 . \quad$ P. $153-183 . \quad$ URL: https://www.academia.edu/19871273/Gower_Handbook_of_Project_Management_4 th_Edition.

10. Ofitsinyi sait Natsionalnoho Erazmus+ ofisu $v$ Ukraini URL: https://erasmusplus.org.ua/erasmus/pro-prohramu.html.

11. Ofitsinyi sait Prohramy transkordonnoho spivrobitnytstva PolshchaBilorus-Ukraina. URL: https://www.pbu2020.eu/ua/pages/251.

12. Kerzner H. Project Management: A Systems Approach to Planning, Scheduling and Controlling. USA. 2003. P. 230-267. URL: https://books.mec.biz/tmp/books/55F1OL4WQC7HL2OBCGHS.pdf.

13. Proekt Stratehii rozvytku vyshchoi osvity v Ukraini na 2021-2031 roky. URL: http://www.reform.org.ua/proj_edu_strategy_2021-2031.pdf.

DOI: https://doi.org/10.36910/2707-6296-2021-18(71)-17

УДК 364-78:614.8.026.1

Сільвестрова О.Ю., к.філос.н., доцент

Майборода О.Л., к.іст.н., доцент

Жук О.М., к.іст.н., доцент

Луцький національний технічний університет

\title{
ГЛОБАЛЬНІ РИЗИКИ ЯК ВИКЛИКИ СУЧАСНІЙ СОЦІАЛЬНІЙ РОБОТІ
}

У статті проаналізовано ризики сучасного світу, які безпосередньо впливають на специфіку, форми і методи соціальної роботи на початку XXI століття. Звернено увагу, що з поширенням пандемії COVID-19 ризики поглибилися та вимагають від соціальних працівників більшої гнучкості у наданні допомоги.

Розглянуто ініціативу Американської академії соціальної роботи та соціального забезпечення «Великі виклики соціальній роботі» та охарактеризовано її основні положення.

Ключові слова: ризик, «суспільство добробуту», «суспільство ризику», «Великі виклики соціальній роботі». 
Економічні науки: збірник наукових праць Луцького національного технічного університету. Серія "Регіональна економіка". Випуск 18 (71). Редкол.: відп. ред. д.е.н., професор Л.Л. Ковальська. Луиьк: ІВВ Луиького НТУ, 2021. 278 с.

\section{Silvestrova O.Yu., Zhuk O.M., Maiboroda O.L. GLOBAL RISKS AS CHALLENGES TO MODERN SOCIAL WORK}

The end of the twentieth and the beginning of the twenty-first century was called the «society of risk» in socio-philosophical research. German social philosopher W. Beck proposed to call this period so. He stressed that the number of risks has increased, and their severity has increased sharply in our time. Moreover, in the context of globalization, social systemic risks go beyond certain regions and countries and become global.

These risks have a significant impact on modern social work, as they require a rapid response to social problems, difficult life situations, as well as require new approaches to solving these problems. Therefore, the article analyzes the main approaches to the idea of «welfare society», which from the 40s - 50s of the twentieth century to the present day has undergone transformation and criticism.

The article presents the connection between the idea of a «welfare society» and the idea of social citizenship. The latter emphasizes the importance of nondiscrimination of certain members of society due to the narrowing of their rights and opportunities due to the fact that they need help.

The outlined problems are directly related to social work, as modern social transformations are happening rapidly. Clients of social work, social workers do not keep up with changes in the social sphere. The challenge is to provide the best customer support based on effective strategies and methods of assistance. Whatever the social conditions, social workers need to balance care and control in working with service users, promote empowerment and protect clients, provide support and carry out observations. Social workers face individual and social tensions and risks, working on changes in the individual and society, working on specific cases and carrying out preventive work.

Therefore, in 2015, the American Academy of Social Work and Welfare identified the so-called «Great Challenges to Social Work» - key issues that require a rapid response to mitigate their negative impact on people's lives, well-being and social security. Such challenges include: ensuring the healthy development of young people, closing gaps in health care, combating domestic violence, increasing life expectancy and productivity, eradicating social exclusion, addressing homelessness, to changes in the environment, use of technologies for social welfare, the promotion of reasonable imprisonment, reduction of extreme economic inequality, the provision of equal financial opportunities for all, the achievement of equal opportunities and justice.

In 2021, the "Great Challenges to Social Work" was supplemented by another - the elimination of racism. The risks have deepened and require more flexibility for social workers to provide assistance in the event of a COVID-19 pandemic.

The conclusions indicate that in the conditions of rapid transformation of society, social workers are faced with the task of providing the most effective 
Економічні науки: збірник наукових праць Луцького національного технічного університету. Серія "Регіональна економіка". Випуск 18 (71). Редкол.: відп. ред. д.е.н., професор Л.Л. Ковальська. Луцьк: ІВВ Луцького НТУ, 2021. 278 с.

assistance and support to their clients, paying attention to social change. Therefore, the risks of the modern world directly affect the specifics, forms and methods of social work at the beginning of the XXI century.

Key words: risk, «welfare society», «risk society», «Great challenges to social work».

\section{Сильвестрова О.Ю., Жук О.Н., Майборода О.Л. \\ ГЛОБАЛЬНЫЕ РИСКИ КАК ВЫЗОВЫ СОВРЕМЕННОЙ СОЦИАЛЬНОЙ РАБОТЕ}

В статье проанализированы риски современного мира, которые непосредственно влияют на специфику, формы и методы социальной работы в начале XXI века. Обращено внимание, что с распространением пандемии COVID-19 риски углубились и требуют от соцциальних работников большей гибкости в предоставлении помощи.

Рассмотрены инициативу Американской академия социальной работы и социального обеспечения «Большие вызовы социальной работе» и охараткеризовано ее основные положения.

Ключевые слова: риск, «общество благосостояния», «общество риска», «Большие вызовы социальной работе».

\section{Постановка проблеми у загальному вигляді та іiі} зв'язок 3 важливими науковими й практичними завданнями. Стан суспільного буття, характерний для кін. XX поч. XXI ст. у соціально-філософській літературі прийнято називати «суспільством ризику». Термін був уперше вжитий німецьким соціальним філософом Ульріхом Беком у 1992 р. у роботі «Від індустріального суспільства до суспільства ризику». У. Бек говорить про те, що «місце спільності потреби займає спільність страху» [1, с. 161], і якщо для кін. XIX - другої половини XX ст. суспільним ідеалом була ідея рівності, то ідеалом сучасного суспільства - безпека, а цінності рівності замінюються на цінності безпеки. Адже загрози і ризики в добу глобалізації міняють свій характер 3 локальних на глобальні, виявляються у всіх сферах суспільного життя, виходять за межі окремої країни, а «міжнародна безпека» перетворюється на «міжнародну небезпеку». 3 огляду на масштабні терористичні акти (за період 2015 - поч. 2021 рр. їх загальна кількість становить більше 80), найбільш продуктивною стає «економіка 
Економічні науки: збірник наукових праць Луцького національного технічного університету. Серія "Регіональна економіка". Випуск 18 (71). Редкол.: відп. ред. д.е.н., професор Л.Л. Ковальська. Луиьк: ІВВ Луиького НТУ, 2021. 278 с.

страху». Безпека стає одним із суспільно організованих споживчих благ [1, с. 10-11]. «Наше суспільство залишкового ризику стало товариством без гарантій, воно незастраховане, i парадокс у тому, що захищеність зменшується по мірі зростання небезпек», - наголошує У.Бек [3, с. 165].

Аналіз останніх досліджень, у яких започатковано вирішення проблеми. У загальному ризики як елемент суспільного розвитку досліджувалися представниками філософської, політологічної та соціологічної думки, зокрема, У. Беком, Д. Беллом, Р. Даррендорфом, Е. Гідденсом, Р. Інглхартом, Н. Луманом, Т. Парсонсом, С. Хантінгтоном та iн.

Питання аналізу та запобігання соціальним ризикам висвітлювали В. Антонюк, С. Березіна, Є. Болотіна, Н. Борецька, Є. Лібанова, В. Капильцова, Т. Семигіна та ін. Проте питання впливу системних глобальних ризиків на сучасну соціальну роботу $\epsilon$ малодосліджене у вітчизняній теорії соціальної роботи.

Цілі статті. Метою дослідження $є$ аналіз впливу системних ризиків та їх вплив на соціальну роботу на поч. XXI століття, а також аналіз т.зв. «Великих викликів соціальній роботі» - глобальних проблем, вирішення яких $є$ першочерговим для системи соціального забезпечення на рівні суспільства.

Виклад основного матеріалу дослідження 3 повним обгрунтуванням отриманих наукових результатів.

3 40-х по 80-ті рр. ХХ ст. відбулися суттєві зрушення у соціальній політиці, що призвело до формування ідеї «суспільства добробуту». Вона була сформульована англійським економістом В.Беверіджем та мала на меті боротьбу 3 «п'ятьма гігантами»: бідність, хвороби, злидні, невігластво та неробство. Послідовник В.Беверіджа, англійський соціолог Т.Х. Маршалл додав до ідеї «суспільства добробуту» таку форму громадянства, як соціальне громадянство, яка охоплювала права на матеріальні ресурси та соціальні послуги. T.X. Маршалл вважав, що соціальне громадянство доповнює та 
Економічні науки: збірник наукових праць Луцького національного технічного університету. Серія "Регіональна економіка". Випуск 18 (71). Редкол.: відп. ред. д.е.н., професор Л.Л. Ковальська. Луиьк: ІВВ Луиького НТУ, 2021. 278 с.

підсилює громадянські та політичні права, які були утверджені у Західній Європі та Північній Америці у XVIII-XIX ст.

На думку англійського соціолога Е. Гідденса, соціальне забезпечення передбачає наявність у громадян не тільки прав, але й обов'язків, які формуються та забезпечуються системою відповідних стимулів і санкцій [1, с. 106-107].

Наслідком звіту В. Беверіджа (1942) стало поступове прийняття урядом Великобританії законодавчих актів щодо соціальних реформ через національне страхування та виплати, медичну службу, освітні реформи, будівництво житла та політику повної зайнятості. Ці реформи були підтримані політиками, значною мірою запроваджені на початку 1950-х рр. та стали основою для створення «соціальної держави». Таким чином у суспільній думці зміцніла і набула сили ідея, що тільки держава може контролювати та вирішувати соціальні проблеми.

Однозначно, з 50-х рр. ХХ ст. відбулися значні зрушення у соціальній політиці. Проте 3 кін. ХX ст. системні загрози та ризики набувають такого розмаху та масштабності, що сучасні дослідники все більш активно заявляють, що відбулася зміна підходів: від «суспільства добробуту» до «суспільства ризику», де відповідальність за соціальне благополуччя покладається не на державу та іiі інституції, а на окремого громадянина. У той же час підкреслюється, що зосередження тільки на ризиках може призвести до того, що потреби окремих осіб та груп можуть лишитися незадоволеними. На думку Н. Лумана, оцінка ризику і готовність його прийняти - це проблема не тільки ментальна, пов'язана зі сприйняттям окремої особи, але перш за все соціальна [2, с.136].

На думку С. Даффі, філософа і соціального новатора, засновника Центру за реформу соціального забезпечення (2009 р.), необхідна зміна соціальних та політичних систем, щоб кожен міг бути повноцінним та активним громадянином. Проте реформа у сфері соціальної роботи та соціального забезпечення неможлива без формування активної громадянської позиції та відповідальності громадян. Залучення громадян до цих питань дає можливість брати участь і створювати умови для гідного 
Економічні науки: збірник наукових праць Луцького національного технічного університету. Серія "Регіональна економіка". Випуск 18 (71). Редкол.: відп. ред. д.е.н., професор Л.Л. Ковальська. Луиьк: ІВВ Луиького НТУ, 2021. 278 с.

життя для усього суспільства. Інакше є загроза дискримінації окремих представників суспільства через звуження їх прав та можливостей саме внаслідок того, що вони самі потребують допомоги [6]. На жаль, соціальна політика європейських держав у першому десятилітті XXI ст. переорієнтувалася на скорочення соціальних допомог, пільг та податкових кредитів, навіть у більших обсягах, ніж того вимагали фіскальні управління $[6$, p. 16].

Американська академія соціальної роботи та соціального забезпечення в виступила 3 ініціативою «Великі виклики соціальній роботі» [5, р. 16], у якій окреслено 12 напрямків, на які слід першочергово звернути увагу:

1. Забезпечення здорового розвитку молоді. Завдання соціальної роботи у цьому напрямку - реалізація програм для кращого розвитку дітей та підтримки їх психічного здоров'я. Проблеми з поведінкою в дитинстві та підлітковому віці часто суттєво впливають на емоційний стан та фінансовий добробут.

2. Усунення прогалин у галузі охорони здоров'я. Акцент робиться на розробці ефективних рішень для подолання обмеженого доступу до медичного обслуговування, дискримінації, бідності (як наслідок - життя в небезпечних для зроворов'я умовах). Расові, етнічні, статеві, вікові ознаки, статус інвалідності, географії проживання, сексуальна та гендерна ідентичність, соціально-економічний статус не повинні ставати на перешкоді доступу до медичної допомоги.

3. Зупинення насильства в сім’ї. Втручання соціальних працівників дозволяють організувати допомогу на ранніх етапах виникнення проблеми та запобігти ії появі у майбутньому. За 5 років реалізації Великих викликів відбулося розширення розуміння даного виклику від жорстокого поводження 3 дітьми та насильства 3 боку інтимних партнерів до насильства на основі відмінностей у владі між домінуючими та недомінуючими групами (стать, раса) i таким, що підтримується переважаючими соціальними нормами та структурами. Мета Великого виклику є амбіційною, але конкретною: зменшити міжособистісне насильство на $10 \%$ протягом десятиліття 
Економічні науки: збірник наукових праць Луцького національного технічного університету. Серія "Регіональна економіка". Випуск 18 (71). Редкол.: відп. ред. д.е.н., професор Л.Л. Ковальська. Луиьк: ІВВ Луиького НТУ, 2021. 278 с.

шляхом зміцнення здорових стосунків.

4. Збільшення тривалості життя та його продуктивності. Глобальна тенденція старіння населення підвищує ризики виникнення та поглиблення проблем, пов'язаних зі здоров'ям, посилює тиск на сферу охорони здоров'я та соціальних послуг. Для соціальних працівників це означає ускладнення розробки програм допомоги особам похилого віку та зміцнення загального стану здоров'я на фоні старіння населення. Розширення завдань цього Великого виклику полягає у розвитку наукових знань, щоб інформувати про розробку справедливої політики та програм у сфері зайнятості, волонтерства, піклування та освіти, щоб максимізувати здоров'я, забезпечити економічну безпеку та більше можливостей для цілеспрямованого життя для різного віку. Цей грандіозний виклик має на меті знищити ейджизм, расизм, сексизм та інші форми гноблення, оскільки вони обмежують такі можливості.

5. Викорінення соціальної ізоляції. Робота у цьому напрямку орієнтована на сприяння соціальній взаємодії одиноких людей із соціумом, що дозволить покращити їх психічне, фізичне та духовне здоров'я. Основна увага приділяється соціальній ізоляції через прояви расизму, ксенофобії, сексизму, джентрифікації та ін., що призводять до індивідуальної та групової соціальної ізоляції на макрорівні. Недавні дослідження показали, що соціальна ізоляція настільки ж небезпечна для здоров'я людини, як i куріння, проте не отримує належної уваги 3 боку громадськості, медиків та політиків. Таким чином, Великий виклик викорінення соціальної ізоляції має на меті виховання громадськості, поширення практики, що базується на фактичних даних, реформування соціальної політики задля поглиблення соціальних зв'язків для людей різного віку. Із настанням пандемії COVID-19 та впровадженням заходів соціального дистанціювання для уповільнення iї поширення, соціальна ізоляція досягла рівня кризи.

6. Вирішення проблеми бездомності. Світова практика соціальної роботи у цьому напрямку орієнтована на програми 
Економічні науки: збірник наукових праць Луцького національного технічного університету. Серія "Регіональна економіка". Випуск 18 (71). Редкол.: відп. ред. д.е.н., професор Л.Л. Ковальська. Луиьк: ІВВ Луиького НТУ, 2021. 278 с.

забезпечення доступного житла, проте в українських реаліях, на жаль, іiі реалізація $є$ проблематичною через високі відсоткові ставки при отриманні кредитів на житло, величезну недостатність державного житлового фонду тощо. Зменшити ризики безпритульності як безпосередньо, так і опосередковано, планується шляхом розширення доступного житла та створення більшої стабільності доходів.

7. Соціальна відповідь на зміни середовища. Вона грунтується на визнанні того, що зміни навколишнього середовища нерозривно пов'язані зі здоров'ям та добробутом людей. Екологічні проблеми, такі як урбанізація, приріст населення та екстремальні погодні явища, також $є$ питаннями соціальної справедливості 3 непропорційним впливом на найбільш вразливі члени суспільства. Одна 3 нових тенденцій у сучасній соціальні роботі - т.зв. «зелена», або «екологічна соціальна робота», пріоритетним завданням якої є гармонійний розвиток людства та навколишнього середовища задля послаблення негативного впливу останнього на соціальні умови життя людей, на сприяння сталому розвитку та протидію екологічній несправедливості [2; 3]. Проте «зелена соціальна робота» не вичерпується лише подоланням складної екологічної ситуації, а спрямована на подолання соціально-політичної та економічної нестабільності як суттєвих причин ії виникнення.

8. Використання технологій для соціального блага. Ефективність надання допомоги окремим особам чи громадам може бути підвищена завдяки використанню цифрових технологій (зокрема, для планування, проведення оцінювання стану клієнтів). Великий виклик використанню технологій для соціального блага є унікальним серед інших викликів тим, що має на меті не вирішити конкретну проблему, а принципово перетворити сферу соціальної роботи щодо ії відношення до технологій. Зокрема, він спрямований на використання великих даних та впровадження інформаційно-комунікаційних технологій для підвищення ефективності соціальних програм, прискорення темпів соціальних змін та зменшення нерівності. Суттєва зміна відбулася у 2020 році, оскільки заходи 
Економічні науки: збірник наукових праць Луцького національного технічного університету. Серія "Регіональна економіка". Випуск 18 (71). Редкол.: відп. ред. д.е.н., професор Л.Л. Ковальська. Луцьк: ІВВ Луцького НТУ, 2021. 278 с.

соціального дистанціювання, пов'язані 3 COVID-19, різко прискорили впровадження технологій на місцях (віддалена робота та навчання 3 використанням відеоконференцій). У цьому сенсі пандемія коронавірусу привернула до цього Великого виклику нову увагу та показала його актуальність.

9. Сприяння розумному позбавленню волі. Соціальні працівники можуть сприяти розумному «розв'язуванню арешту» - виведенню осіб з інституцій - і знаходити ефективні способи зменшити кількість осіб, які потрапляють до в'язниць, пропонуючи при цьому достатні рішення для загальної громадської безпеки. Одним із засобів вирішення даної проблеми є процедура пробації, зокрема, досудова, наглядова та пенітенціарна пробація.

10.3меншення надзвичайної економічної нерівності. Необхідно подолати розбіжність між податками та доходами еліти та людей 3 низьким рівнем заробітної плати для зменшення крайньої економічної рівності. Щоб зменшити нерівність у багатстві та доходах, подолати фінансові прогалини між расовими групами та між чоловіками й жінками, стратегії включають створення нових робочих місць, зниження податку на прибуток, програми переказу готівки та доступ до догляду за дітьми, а також посилення трудових стандартів та розробку нової політики для заохочення інклюзивного, поступового нарощування багатства.

11.Фінансові можливості для всіх. Нова соціальна політика, спрямована на підтримку отримання доходів та зменшення економічних труднощів, дозволяє соціальним працівникам ефективніше обслуговувати сім'ї 3 фінансовими проблемами. Великий виклик побудови фінансової спроможності та активів для всіх гарантує, що всі люди матимуть доступ до фінансової політики, послуг, підтримки, знань та інструментів, що дозволяють їм досягти фінансової стабільності та безпеки.

12.Досягнення рівних можливостей та справедливості. Перешкодою для доступу до освіти та можливостей працевлаштування $є$ упередження. Тому протидія расизму, 
Економічні науки: збірник наукових праць Луцького національного технічного університету. Серія "Регіональна економіка". Випуск 18 (71). Редкол.: відп. ред. д.е.н., професор Л.Л. Ковальська. Луиьк: ІВВ Луиького НТУ, 2021. 278 с.

стереотипам та іншій несправедливості збільшує можливості для кожного у просуванні в суспільстві. Великим викликом досягнення рівних можливостей та справедливості визнається кричуща нерівність у доступі до медичного обслуговування, доступного житла, якісної освіти та отримання прибутку. Він вбачає життєво важливу роль соціальної роботи у реконструкції основних упереджень та стигматизації, що посилюють цю несправедливість. Соціальні працівники розглядаються як чинники змін у своїх громадах та установах.

У січні 2021 р. були підведені підсумки 5-річної роботи по «Великих викликах» та визначено цілі на наступні 5 років. До Великих викликів соціальної роботи був доданий ще один усунення расизму. Значимість цього виклику посилилася внаслідок подій у 2020 р. у США, коли дії поліції призвели до смерті чорношкірих американців, що викликало масові протести та породило рух Black Lives Matter [7].

Висновки. Суспільство трансформується швидкими темпами, і перед соціальними працівниками постає те ж саме завдання, щоб надавати найбільш ефективну допомогу та підтримку своїм клієнтам. Професіонали соціальної роботи знайомляться зі справами, в яких зосереджено насильство, зловживання наркотиками, ізоляцію, нерівність тощо. Завдяки досвідченому, належному навчанню та позитивному настрою соціальні працівники по всій країні розробили стратегії вирішення цих проблем, але багато проблем залишаються.

\section{Список бібліографічного опису}

1.Гидденс Э. Неспокойный и могущественный континент: что ждет Европу в будущем? М.: Издат. дом «Дело» РАНХ и ГС, 2015. 240 с.

2. Луман Никлас. Понятие риска. THESIS. 1994, вып. 5. С. 135-160. URL : https://igiti.hse.ru/data/423/313/1234/5_2_2Luhm.pdf (дата звернення 14.09.2021)

3.Семигіна Т. В. Зелена соціальна робота: чи потрібна вона Україні? Сучасні проблеми екологічної психології: життєве середовище особистості у психологічному вимірі: матеріали IV Міжнародної науково-практичної конференції (18 - 19 травня 2018 року, Київ) / за ред. Ю.М. Швалба. Київ : Інститут психології імені Г.С. Костюка НАПН України, 2018. С. 105-109. URL

https://www.researchgate.net/publication/325300591_ZELENA_SOCIALNA_ROB OTA CI POTRIBNA VONA UKRAINI (дата звернення 14.09.2021) 
Економічні науки: збірник наукових праць Луцького національного технічного університету. Серія "Регіональна економіка". Випуск 18 (71). Редкол.: відп. ред. д.е.н., професор Л.Л. Ковальська. Луиьк: ІВВ Луцьького НТУ, 2021. 278 с.

4. Семигіна Т. Чому соціальна робота набуває зеленого кольору? Вісник Академії праці, соціальних відносин і туризму. 2018. № 2. С. 11-27. URL : http://nbuv.gov.ua/UJRN/VAPSV_2018_2_4 (дата звернення 02.10.2021)

5. Coyle, Sue . The Grand Challenges for Social Work: An Update. Social Work Today. Vol. 19 No. 5 P. 16. URL : https://www.socialworktoday.com/archive/SO19p16.shtml (дата звернення $\frac{14.09 .2021)}{6.0 u f(y)}$

6.Duffy, Simon. Citizenship and the Welfare State. The centre for welfare reform. URL https://www.centreforwelfarereform.org/uploads/attachment/487/citizenship-andthe-welfare-state.pdf p.16 (дата звернення 02.10.2021)

7.Progress and Plans for the Grand Challenges. An Impact Report at Year 5 of the 10-Year Initiative. Grand Challenges. URL : https://grandchallengesforsocialwork.org/wp-content/uploads/2021/01/GCSWImpact-Report.pdffor Social Work. (дата звернення 14.09.2021)

\section{References}

1. Hyddens Э. Nespokoinыi y mohushchestvennыi kontynent: chto zhdet Evropu v budushchem? M.: Yzdat. dom «Delo» RANKh y HS, 2015. 240 s.[In Russsian]

2. Luman Nyklas. Poniatye ryska. THESIS. 1994, vыр. 5. S. 135-160. URL : https://igiti.hse.ru/data/423/313/1234/5_2_2Luhm.pdf (data zvernennia 14.09.2021) [In Russsian]

3. Semyhina T.V. Zelena sotsialna robota: chy potribna vona Ukraini? Suchasni problemy ekolohichnoi psykholohii: zhyttieve seredovyshche osobystosti u psykholohichnomu vymiri: materialy IV Mizhnarodnoi naukovo-praktychnoi konferentsii (18 - 19 travnia 2018 roku, Kyiv) / za red. Yu.M. Shvalba. Kyiv : Instytut psykholohii imeni H.S. Kostiuka NAPN Ukrainy, 2018. S. 105-109. URL : https://www.researchgate.net/publication/325300591 ZELENA SOCIALNA ROB OTA_CI_POTRIBNA_VONA_UKRAINI (accessed 14.09.2021) [in Ukrainian]

4. Semyhina T. Chomu sotsialna robota nabuvaie zelenoho koloru? Visnyk Akademii pratsi, sotsialnykh vidnosyn i turyzmu. 2018. № 2. S. 11-27. URL : http://nbuv.gov.ua/UJRN/VAPSV_2018_2_4 (accessed 02.10.2021)[in Ukrainian]

5. Coyle, Sue . The Grand Challenges for Social Work: An Update. Social Work Today. Vol. 19 No. 5 P. 16. URL : https://www.socialworktoday.com/archive/SO19p16.shtml (accessed 14.09.2021)

6. Duffy, Simon. Citizenship and the Welfare State. The centre for welfare reform. URL https://www.centreforwelfarereform.org/uploads/attachment/487/citizenship-andthe-welfare-state.pdf p.16 (accessed 02.10.2021)

7. Progress and Plans for the Grand Challenges. An Impact Report at Year 5 of the 10-Year Initiative. Grand Challenges. URL : https://grandchallengesforsocialwork.org/wp-content/uploads/2021/01/GCSWImpact-Report.pdffor Social Work. (accessed 14.09.2021)

DOI: https://doi.org/10.36910/2707-6296-2021-18(71)-18 